IZABELLA BUKRABA-RYLSKA

Instytut Rozwoju Wsi i Rolnictwa PAN

Warszawa

\title{
Profesor Maria WieruszewsKa W InSTytucie RozWoJU WSi I RolnictWA PAN
}

6 ainteresowania, jakie Profesor Maria Wieruszewska rozwijała w czasie swojej pracy w Instytucie Rozwoju Wsi i Rolnictwa PAN w Warszawie (począwszy od lat siedemdziesiątych aż do chwili obecnej) i którym dawała wyraz w podejmowanych badaniach, owocujących następnie licznymi publikacjami książkowymi oraz artykułami zamieszczanymi w czasopismach naukowych i pracach zbiorowych, można określić jednym słowem: wieś, a ściślej - dwoma słowami: polska wieś.

Takie stwierdzenie, choć słuszne, może być jednak zaledwie punktem wyjścia do bardziej dokładnej charakterystyki. Obszar obrany za przedmiot refleksji jest bowiem traktowany w Jej dorobku w szczególny sposób: syntetycznie, jako pewna systemowa całość, ale zarazem analitycznie, gdy z precyzją wytrawnego badacza penetruje Ona skomplikowane wzory i relacje w tkance wiejskich społeczności; z szacunkiem dla wcześniejszych dokonań w tym zakresie, ale i z ambicją sprostania współczesnym wyzwaniom tak empirycznym, jak i teoretycznym; z erudycją nakazującą uwzględnianie całego spektrum koncepcji na dany temat, lecz również z wyraźną preferencją dla niektórych z nich i jednocześnie z nie mniej widoczną pasja polemiczną wobec innych omawianych stanowisk. Wszystko to sprawia, że dorobek naukowy Profesor Wieruszewskiej z minionego czterdziestolecia można uznać za wręcz wzorcowy przykład pełnej troski o sprawy warsztatowe, ale też nacechowanej głębokim zaangażowaniem działalności badaczahumanisty. Spróbujmy przybliżyć zasygnalizowane tu kwestie w nastę- 
pującej kolejności: wieś (czyli przedmiot refleksji), metoda (czyli warsztat badawczy), wartości (czyli świadome zaangażowanie i etos badacza).

Wieś, nad którą od początku swojej kariery Jubilatka się pochyla, nie jest nigdy fantomem zrodzonym z doktrynalnych założeń (czy to marksistowskich - jak w okresie PRL-u, czy też neoliberalnych - jak w okresie transformacji), które tak często znajdują sposób, by przeniknąć do aparatury pojęciowej naukowca. W tekstach, które wyszły spod Jej ręki jest to zawsze wieś prawdziwa, bo realna i konkretna, w dodatku umieszczona w ściśle określonym - diachronicznie, synchronicznie, ale też problemowo i aksjologicznie - kontekście. Do tych pojęć, wyniesionych z łódzkiej szkoły etnograficznej, Autorka odwołuje się w swoich pracach wielokrotnie, wiążąc je z osobą swojej Mistrzyni - Kazimiery Zawistowicz-Adamskiej. Zasada „konkretu i kontekstu" jest więc obecna w jej kolejnych pracach zawierających relacje z badań empirycznych (Sankcje systemu kontroli społecznej wobec rodziny wiejskiej z roku 1971, którą niejako żegnała się ze środowiskiem łódzkim; Przemiany społeczności wiejskiej Zaborów z 1978 r. i Społeczność wiejska Zaborowa w procesie przemian z 1980 r., gdzie doprowadziła do końca jeszcze przedwojenne zamierzenia prof. Zawistowicz-Adamskiej, polegające na analizie skutków migracji zarobkowych dla środowiska wiejskiego; Samoorganizacja w społecznościach wiejskich z 2002 r. zawierającej powtórną analizę porównawczą wsi wielkopolskiej i podlaskiej; czy wreszcie Tu i tam. Migracje z polskich wsi za granicę z 2007 r.), ale też w tekstach poświęconych rozważaniom teoretycznym (takich jak Wieś. $W$ poszukiwaniu całości społeczno-kulturowej z 1991 r. czy Wieś polska. Konteksty - kontrasty - strategie z 1997 r.). Kontekst, przypomina Autorka w pracy o samoorganizacji, to przede wszystkim umiejscowienie zjawisk w czasie i przestrzeni, ale nie tylko. Kontekstem są również rozmaite pola odniesień, w których badacz sytuuje podejmowaną przez siebie problematykę, wreszcie sama wieś może być uznana za kontekst, pozwalający w nowym świetle postrzegać inne problemy, a zwłaszcza diagnozować i oceniać wyzwania przyszłości.

Wieś to dla nas zawsze swoisty wzór - pisze Wieruszewska - specyficzny układ powiązań w przestrzeni i czasie, obecny w życiu przeszłych i żyjących pokoleń mieszkańców. Wzorotwórcza, strukturalizująca siła tej matrycy nie odziera jednostek z ich wolności i podmiotowości, lecz tworzy zasób, z którego ludzie czerpią interpretację sensu doświadczanej przez siebie rzeczywistości ${ }^{1}$.

${ }^{1}$ M. Wieruszewska, Samoorganizacja w społecznościach wiejskich, IRWiR PAN, Warszawa 2002, s. 20. 
W tym ostatnim przypadku pojęcie kontekstu nabiera znaczenia aksjologicznego, gdyż wieś w rozumieniu Autorki to „raczej świat wzorów i konfiguracji niż statystycznych zależności", to zjawisko określone przez znaczenia i wartości, a więc całość kulturowa.

Dzięki konsekwentnemu zastosowaniu dyrektywy „konkretu i kontekstu" wieś omawiana przez Profesor Wieruszewskąjest prezentowana zawsze jako układ otwarty, ale zarazem wyraźnie wyodrębniający się z otoczenia, stanowi więc pośredni i niezbędny element całego systemu społecznego, nie przestając jednak być światem o dynamice wyznaczonej przez własne cechy i tożsamość, przez posiadane zasoby i doświadczane koleje losu. Holistyczna i jednocześnie kulturowa perspektywa ma zatem tutaj tę zaletę, że uzasadnia przeciwstawienie się traktowaniu wsi wyłącznie w kategoriach funkcjonalnego podsystemu, wytworzonego przez społeczeństwo globalne dla zaspokajanie określonych potrzeb struktur nadrzędnych, i staje się punktem wyjścia dla podmiotowego traktowania środowisk wiejskich, co nie oznacza, że wieś ma być jakimś homogenicznym organizmem. W istocie tworzy ona swoisty mikrokosmos o bardzo skomplikowanej strukturze wewnętrznej i różnorodnych relacjach z otoczeniem zewnętrznym. Tę misterną sieć zależności bardzo dobrze pokazały obie prace o Zaborowie, gdzie Autorce udało się połączyć etnograficzną wrażliwość na szczegół z socjologiczną analizą strukturalnych i funkcjonalnych powiązań różnych wymiarów życia wiejskiej społeczności. Jak pisała we wstępie do drugiej z wymienionych książek poświęconych Zaborowu:

Można sądzić, że materiał tej pracy powstał z analizy różnych, luźno ze sobą związanych dziedzin życia, a zatem dobrano go na zasadzie troski o kompletność wszystkiego, co ważne we wsi i dla wsi. Rzecz przedstawia się jednak inaczej. Uwagę skupiają tylko pewne sfery życia, te mianowicie, w których najsilniej przejawiają się funkcje społeczności².

I rzeczywiście, precyzyjne rozróżnienie dwu wymiarów integracji (lokalnego i ponadlokalnego) oraz jej poziomu kulturowego, komunikatywnego, normatywnego i funkcjonalnego umożliwiło zakwestionowanie ideologicznie zadekretowanych ogólnikowych sądów o nieuchronnie postępującej dezintegracji wsi.

${ }^{2}$ Tejże, Społeczność wiejska Zaborowa w procesie przemian, PWN, Warszawa 1980, s. 10. 
Obserwowane przejawy integracji komunikatywnej, widoczne w sieci kontaktów i styczności wewnątrzwiejskich, oraz przejawy integracji funkcjonalnej, manifestowane przez wysoki wskaźnik instytucjonalizacji życia wsi i zaspokajania jej podstawowych potrzeb, mimo słabszej integracji kulturowej i normatywnej, pozwalają uznać wieś za całość funkcjonalnie powiązanych elementów. Elementy te, ulegając zmianom, różnicują cały układ i dają tym samym wyraz procesom, w których wieś uczestniczy ${ }^{3}$.

Ze szczególną nieufnością Profesor Wieruszewska traktuje także inne stereotypowe przekonania na temat wsi, zwłaszcza te, streszczające się w przeciwstawieniu: „tradycyjne” i „nowoczesne”, przy czym nie ogranicza się do wytknięcia ograniczeń koncepcji wzrostu, rozwoju i modernizacji, ale również precyzyjnie wykazuje na materiale empirycznym ich ewidentną zawodność. Takie podejście zaprezentowała w publikacji o sankcjach systemu kontroli, gdzie badania prowadzone w okolicach Bełchatowa dowiodły, iż wieś uznawana za bardziej rozwiniętą (środowisko otwarte, rozproszone, z większą ilością ludności robotniczej) stosuje rozwiązania typowe raczej dla środowisk tradycjonalnych, to znaczy odwołuje się do radykalnych działań w sferze publicznej i czyni to z pełną jawnością, podczas gdy wieś pozornie bliższa biegunowi „wspólnoty” (z silnymi więziami rodzinnymi, rezerwą wobec obcych i przewagą rolników) dopuszcza jedynie działania mniej drastyczne i tylko wobec osób spokrewnionych.

Do podobnych wniosków, niezgodnych z uproszczonymi wyobrażeniami i poznawczymi kliszami socjologii, doprowadziły Autorkę - podjęte po kilkunastu latach od pierwszego badania - analizy samoorganizacji mieszkańców wsi wielkopolskiej (uznawanej zawsze za bardziej rozwinięta) i podlaskiej (traktowanej zwykle jako relatywnie zacofana). I znów nie potwierdziły się „oczywiste prawidłowości”, które nakazywałyby dostrzegać wyraźnie słabsze zaangażowanie w sprawy wspólne wśród mieszkańców wsi „mniej zmodernizowanej”. Rzeczywistość ponownie okazała się bardziej skomplikowana niż zwyczajowo stosowane w naukach społecznych schematy. Wieś wielkopolska w świetle oficjalnych danych była wprawdzie w okresie PRL-u zdecydowanie „nowoczesna”, cieszyła się wysokim poziomem produkcji rolnej i umiejętnie korzystała z oferty dostarczanej przez instytucjonalne otoczenie, ale proces transformacji odbił się na niej wyjątkowo niekorzystnie, w dodatku w nowych warunkach wykazywała tylko

\footnotetext{
3 Tamże, s. 133.
} 
nieznacznie większy poziom samoorganizacji, mierzonej syntetycznym wskaźnikiem (struktury współpracy, „wrażliwość” obywatelska, poziom uczestnictwa, zaufanie). Natomiast wieś podlaska, poprzednio „buntująca się przeciw systemowi” i funkcjonująca dzięki tradycyjnym zasobom (głównie współpracy rodzinno-sąsiedzkiej), po roku '89 dużo lepiej radziła sobie z wyzwaniami gospodarki rynkowej, a i pod względem zaangażowania i struktur współpracy przewyższała tę wielkopolską. Metoda „konkretu i kontekstu" nakazująca wyżej cenić precyzyjną analizę szczegółu in vivo niż gabinetowe teoretyzowanie in vitro i odwołująca się raczej do „mikroskopu” niż „lunety” po raz kolejny dowiodła swej słuszności. Pozwoliła mianowicie na empiryczne potwierdzenie istnienia różnych rodzajów kapitału społecznego („wspólnotowego" i „stowarzyszeniowego”) i różnych wzorów samoorganizacji („miejskiego” i „wiejskiego”), zwracając jednocześnie uwagę na niedopuszczalność przenoszenia tych modeli z jednego typu środowiska społecznego na inny.

Stosowana przez Profesor Wieruszewską z pełną premedytacją zasada systematycznego testowania hipotez „wątpliwych a priori”, jeszcze raz okazała swoją wartość w badaniach nad migracjami zarobkowymi, które podjęła w pierwszych latach po akcesji. Podzielane powszechnie przekonanie (wręcz aksjomat w naukach społecznych), iż mobilność przestrzenna przekłada się na bardziej otwarte postawy i opinie, nie znalazło potwierdzenia w wynikach analizy trzech środowisk wiejskich z różnych regionów kraju. Na Podlasiu najniższy stopień zaangażowania migracyjnego łączył się z najniższym wskaźnikiem tradycjonalizmu; na Opolszczyźnie obie miary wykazywały wartości średnie, zaś na Podkarpaciu maksymalny stopień zaangażowania migracyjnego towarzyszył maksymalnemu poziomowi tradycjonalizmu. Również bynajmniej nie jednoznaczne okazały się konkluzje dotyczące rozważań nad kapitałem ludzkim, społecznym i kulturowym: wyraźnie akcentowane przez rozmówców korzyści w sferze indywidualnej niekoniecznie przekładały się na pozytywne zjawiska w wymiarze kulturowym, zwłaszcza postrzeganym w perspektywie długiego trwania, a kapitał społeczny okazywał się efektem nie wyłącznie sieci powiązań (co zwykła podkreślać koncepcja liberalna), lecz wspierał się „na takich kulturowo wytworzonych cechach, jak normy współdziałania, współpracy, powinności odwzajemniania zobowiązań i poczucia zaufania" (uwzględnianych 
przez perspektywę komunitariańską). To zaś - zdaniem Autorki - „wskazuje na jego związki z kapitałem kulturowym poprzez kontekst wartości, ale też z kapitałem ludzkim w sensie indywidualnych kompetencji, cnót osobistych" ${ }^{\prime \prime}$.

Przedstawione dotychczas kierunki zainteresowań Profesor Wieruszewskiej dowodzą, iż w swoim podejściu do problematyki wiejskiej pozostaje Ona wierna zasadzie „konkretu i kontekstu”. Z ogromną wrażliwością traktuje badane szczegóły, niuanse sytuacji czy indywidualne przypadki i jednocześnie potrafi wnikliwie ocenić złożone relacje między różnymi elementami z poziomu zarówno układu mikro-, mezo- czy makro. Dzięki temu wieś przestaje być obszarem, na którym po prostu zachodzą zjawiska czy prawidłowości powszechnie występujące gdzie indziej, a zaczyna jawić się jako miejsce, gdzie dochodzi do bardzo nietypowego przekształcania ogólnych tendencji. A dzieje się tak dlatego, co Autorka zawsze podkreśla, ponieważ ogólne trendy trafiają tam na specyficzne środowisko społeczne, odmienne podłoże kulturowe i na jednostki o szczególnym poczuciu tożsamości. Wszystko to sprawia, że wnikliwe przyjrzenie się mikroskali i prawidłowe zastosowanie „mikroskopu” nie tylko pozwala dostrzec wyraźniej procesy widoczne także „przez lunetę”, ale niejednokrotnie pozwala również zauważyć coś zupełnie innego. Dzięki stosowanej przez Nią procedurze „etnografizowania socjologii” polska wieś przestaje też być biernym przedmiotem interwencji ze strony społeczeństwa globalnego, „czymś, co tylko przeżywa i przeżuwa, a nie tworzy i dąży" - jak o powszechnym mniemaniu na temat wsi pisał z ubolewaniem Władysław Grabski ${ }^{5}$ - lecz staje się podmiotem o własnym potencjale rozwojowym. Obrane przez Jubilatkę zasady metodologiczne mają jednak wpływ nie tylko na prezentowany przez Nią obraz wiejskiej rzeczywistości, ale zarazem pozwalają bardzo wyraziście scharakteryzować Jej warsztat badawczy i sylwetkę Jej samej jako badacza.

Profesor Wieruszewska nie podejmuje tematów przypadkowych, nie kieruje się aktualnym zapotrzebowaniem, które sprawia, że - jak twierdzi Pierre Bourdieu - socjologia traci swą autonomię, dla chwilowych korzyści przekształcając problemy publiczne w problemy naukowe ${ }^{6}$, nie stosuje też modnych koncepcji bez uprzedniego skonfrontowania ich z dotychczasową

${ }^{4}$ Tejże, Tu i tam. Migracje z polskich wsi za granicę, IRWiR PAN, Warszawa 2007, s. 18.

5 W. Grabski, System socjologii wsi, „Roczniki Socjologii Wsi”, T. I, 1936, s. 71.

${ }^{6}$ P. Bourdieu, Zaproszenie do socjologii refleksyjnej, tłum. A. Sawisz, Oficyna Naukowa, Warszawa 2001, s. 179. 
aparaturą pojęciową uprawianej przez siebie dyscypliny. Za Jej wyborami stoją zawsze racje głębsze, wyprowadzone z refleksji nad długim trwaniem społeczności wiejskich, a zarazem osadzone w tradycjach i etosie przede wszystkim polskiej etnologii i socjologii wsi. Takimi zjawiskami obecnymi „od zawsze” na polskiej wsi były niesformalizowane i niezinstytucjonalizowane fakty współdziałania czy samoorganizacji oraz inne przejawy więzi społecznej (chociażby system kontroli i sankcji). Dla ich należytego zrozumienia stosowane współcześnie terminy takie jak „,kapitał społeczny” okazują się niewystarczające, zwłaszcza jeśli są definiowane zgodnie z miejskim i stowarzyszeniowym modelem społeczeństwa obywatelskiego, który zapoznaje reguły funkcjonowania tradycyjnych wiejskich wspólnot. Od dawna też polska wieś doświadczała migracji zarobkowych i dlatego ich wyjaśnienia nie warto poszukiwać tylko w najbliższej przeszłości PRL-u („niedokończona urbanizacja”), ale w o wiele odleglejszej historii naznaczonej asymetrycznymi relacjami segmentu agrarnego i społeczeństwa globalnego. Dopiero przy zastosowaniu takiej perspektywy ujawniają się pewne, leżące głębiej mechanizmy. Widać wówczas wyraźnie, że określany przez makroekonomistów eleganckim mianem „przepływów międzygałęziowych” systematyczny i rabunkowy drenaż wsi i rolnictwa w połączeniu z traktowaniem ich jako naturalnego rezerwuaru siły roboczej, zasobów materiałowych i środków finansowych, a w miarę potrzeby także jako bufora przemian, amortyzatora kryzysów i „gąbki chłonącej bezrobocie”, zawsze powodował negatywne konsekwencje dla środowisk wiejskich, generując zarazem (od XV wieku) efekt „paradoksu modernizacyjnego” dla pozostałych dziedzin gospodarki. Krótkotrwały rozwój reszty kraju, okupowany kolejnymi zapaściami rolnictwa, nieodmiennie skutkował pogarszaniem się struktury agrarnej, przeludnieniem, obniżeniem poziomu życia mieszkańców wsi i - w rezultacie - ich migracjami zarobkowymi, nierzadko zagranicznymi, na szczęście z reguły wahadłowymi, a więc niedefinitywnymi. Od początku naukowego zainteresowania polską wsią były także obecne w refleksji badaczy wątki dotyczące specyfiki tego środowiska społecznego, wyjątkowości jego kultury oraz ich adekwatności wobec aktualnych tendencji rozwojowych i wyzwań cywilizacyjnych. Opiniom negującym jakąkolwiek wartość kulturowego dorobku wsi (jakie bardzo chętnie formułowano w okresie PRL-u, ale i po roku '89) Profesor Wieruszewska zawsze przeciwstawiała odmienne zdanie, znajdując dla wsparcia swego 
stanowiska wiele istotnych i zasługujących na przemyślenie argumentów. Ponieważ ten aspekt Jej dorobku dotyczy założeń aksjologicznych i sfery wartości, znajdzie swoje omówienie w końcowym fragmencie niniejszych rozważań. Teraz natomiast warto zatrzymać się jeszcze przez chwilę na kwestiach warsztatowych Jubilatki.

Preferencja dla zagadnień nie efemerycznych, ale niejako strukturalnie zakorzenionych w mechanizmach trwania i zmiany polskiej wsi, pociąga za sobą wybór takich metod, którymi posługiwano się niegdyś, gdyż dowiodły one już nieraz swojej przydatności i - dla uzyskania porównywalnych wyników kolejnych analiz - powinny znaleźć kontynuację także obecnie. Stąd w pracach Profesor Wieruszewskiej odwołania do metody, którą kiedyś słynęła polska socjologia - monograficznej, w dodatku w jej rozmaitych odmianach (porównawczej - w porządku synchronicznym - oraz ponownej - w ujęciu diachronicznym) i stosowanie z powodzeniem metody studium przypadku. Stąd uzupełnianie bardziej zestandaryzowanych metod socjologicznych (na przykład wywiad kwestionariuszowy na większej próbie) także podejściami bardziej „miękkimi” (wywiad narracyjny, obserwacja uczestnicząca). Stąd wreszcie szacunek dla dokonań poprzedników, do których dzieł zawsze chętnie się odwołuje, i szczególna atencja dla niektórych z nich jako autorytetów nie tylko naukowych. Obecne w pracach Autorki odniesienia do najnowszej literatury przedmiotu, zarówno polskiej jak i zagranicznej, są więc zawsze uzupełnione doskonała znajomością wcześniejszych, klasycznych, ale i mniej znanych opracowań. Swoją postawę Autorka tak wyjaśnia w jednym z najnowszych tekstów, poświęconych aktualności myśli Floriana Znanieckiego dla badań nad migracją:

Nie negując potrzeby stworzenia w socjologii, ale i w antropologii nowego słownika, bardziej adekwatnego do tłumaczenia świata globalizacji, chcę uniknąć błędu zaprzepaszczenia tych cennych dokonań humanistyki, które zachowują - moim zdaniem - swoją użyteczność. Ich rozważne, refleksyjne przywołanie może zmniejszyć, jeśli nie całkiem oddalić, zarzut nieadekwatności pojęć, które przypominają biblijną scenę nalewania starego wina do nowych bukłaków z łatwym do przewidzenia skutkiem. Widzę więc sens płynący z posługiwania się pojęciami z kulturowego wokabularza etnologii, pojęciami takimi jak: kontakt kulturowy, asymilacja, adaptacja, akulturacja, dyfuzja. Wszystkie one podkreślają wagę kulturowego zaplecza: wartości, norm, tego, co Florian Znaniecki nazwał systemem aksjonormatywnym7.

${ }^{7}$ M. Wieruszewska, Dzieło „Chłop polski w Europie i Ameryce”, czyli o pożytkach z czytania klasyków, „Studia Migracyjne - Przegląd Polonijny” 2012, nr 2, s. 5-23. 
Ze względu na tę właśnie troskę o zachowanie ciągłości dyscypliny publikacje Profesor Wieruszewskiej można uznać za chwalebny wyjątek od nieszczęsnej reguły, jaką już w 1917 roku skonstatował dla polskiej socjologii Jan Stanisław Bystroń. Zauważył on mianowicie niepokojącą tendencję polegającą na tym, że polscy autorzy „znajdują się zawsze w żywym kontakcie z teoriami obcymi, nie znając przeważnie poprzednich prac polskich". Polska socjologia nie ma więc rozwoju historycznego, twierdził Bystroń, a jedynie logiczny ${ }^{8}$. 0 słabościach takiej postawy - dominującej również współcześnie - pisze się dzisiaj na szczęście coraz więcej. Przykładowo, Ewa Domańska krytykuje polską metodologię i teorię humanistyki, zarzucając jej czysto instrumentalne przykładanie do rodzimego materiału obcych teorii (niczym gotowych „skrzynek z narzędziami”), zamiast traktować je jako inspirację do tworzenia własnych koncepcji. Domańska nie ma wątpliwości, że tego rodzaju praktyka stanowi przejaw „intelektualnej autokolonizacji" badaczy z peryferii, którzy (dokładnie tak, jak to przewiduje teoria postkolonialna) sami się prowincjalizują uznając, że to „centrum” dostarcza teorii, a „peryferie” jedynie materiału empirycznego dla ich potwierdzenia9. Jubilatka jest wyjątkowo wyczulona na wszelkie takie niefortunne zapożyczenia, uznając je nie tylko za przejaw słabości metodologicznej, ale i za gwałt na badanej rzeczywistości.

Pragnienie nadążania za „umykającym światem” - pisze w artykule poświęconym współczesnym dyskursom na temat wsi i rolnictwa - łatwo rozgrzesza z porzucenia dawnych narzędzi i słowników. Zastępują je nowe tropy i metafory... Uwiedzenie przez „modne” koncepcje, niejako „wyprzedzające” wobec empirycznych świadectw chwili obecnej, wywołuje inny rodzaj niedosytu. Pozostają niezagospodarowane pola zainteresowań niegdysiejszych ${ }^{10}$.

Wydaje się więc, że Profesor Wieruszewska podpisałaby się pod propozycją Domańskiej, gdy ta jako remedium na wszelkie tego rodzaju zagrożenia proponuje swoisty „atawizm” badawczy rozumiany nie w kategoriach regresu, ale chęci przekazywania w trakcie rozwoju wykształconych już cech gatunkowych, które przesądzają o zdolności do przetrwania i do autoregeneracji dyscypliny, a więc o utrzymaniu jej tożsamości. Z pewnością

\footnotetext{
${ }^{8}$ J. St. Bystroń, Rozwój problemu socjologicznego w nauce polskiej, [w:] Sto lat socjologii polskiej, pod red. J. Szackiego, PWN, Warszawa 1995, s. 538-540.

${ }_{9}$ E. Domańska, Historia egzystencjalna, PWN, Warszawa 2012, s. 176.

${ }_{10}$ M. Wieruszewska, Współczesne dyskursy na temat wsi i rolnictwa, [w:] Polacy o sobie, pod red. P. Kowalskiego, Oficyna Wydawnicza „Stopka”, Łomża 2005, s. 207-226.
} 
też Profesor Wieruszewska poparłaby inny pomysł Domańskiej, która tak modnej dziś re-dyscyplinizacji, „mąceniu gatunków” i niefrasobliwemu „kłusownictwu” po cudzych obszarach przeciwstawia mocno dyscyplinujący postulat re-dyscyplinizacji, gdyż tylko to (zdaniem historyczki) jest w stanie zapobiec „procesom przenikania się różnych dyscyplin badawczych, którym towarzyszy przekonanie, że bez znajomości teorii i praktyki metod specyficznych dla danej dyscypliny każdy może się zająć wszystkim"11. Stawką w grze, toczonej dziś w obrębie humanistyki, jest - jak widać - nie tylko mniej lub bardziej trafna diagnoza rzeczywistości, ale również suwerenność, koherencja i ciągłość danej dyscypliny naukowej, co w żadnym razie nie wyklucza idei badań interdyscyplinarnych, lecz właśnie stanowi ich przesłankę. Za podstawowy warunek zachowania tej ciągłości trzeba jednak, za Ewą Domańską, uznać coś więcej niż sam przedmiot badania. W nie mniejszym stopniu chodzi tu również o „erudycje”, czyli gruntowną znajomość dziejów dyscypliny, dotychczas podejmowanych tematów, już zrealizowanych przedsięwzięć oraz używanych metod. To wszystko są cechy dorobku Jubilatki i właśnie w tym leży przyczyna Jej niezgody na formułowane - bez należytej znajomości rzeczy bądź na podstawie założeń wywiedzionych z innych dziedzin - sądy o polskiej wsi. Te wątki twórczości Profesor Wieruszewskiej należą jednak do trzeciego z wyszczególnionych na początku aspektów, a mianowicie do sfery aksjologicznej: uznawanych i zarazem praktykowanych wartości, czyli etosu badacza.

Do najważniejszych z nich można zaliczyć przekonanie o wyższości naturalnego, ewolucyjnego i endogennego rozwoju nad rozwiązaniami rewolucyjnymi, stanowiącymi zawsze nagłą i brutalną ingerencję z zewnątrz w skomplikowane mechanizmy danej całości. Jubilatka podziela skłonność właściwą wszystkim osobowościom o nastawieniu konserwatywnym „do używania kategorii morfologicznych, które nie rozkładają na części materiału $\mathrm{z}$ doświadczenia $\mathrm{w}$ jego poglądowej totalności, lecz próbują zachować jego niepowtarzalność". Przeciwieństwem tego typu postawy w interpretacji Karla Mannheima jest właściwa lewicowcom metoda analityczna, „która każdą napotkaną całość najpierw rozbija by dojść stopniowo do dających się ze sobą kombinować i generalnie określić elementów i łączyć je potem według mechanizmu funkcjonowania lub poprzez kategorię

${ }^{11}$ D. Domańska, dz. cyt., s. 164. 
przyczynowości”. Osobowościowe predylekcje Jubilatki musiały doznać wzmocnienia w środowisku takim jak IRWiR w konfrontacji z najzupełniej przeciwstawną opcją, którą Mannheim tłumaczył następująco:

\begin{abstract}
lewicowi myśliciele chcą z zastanego świata zrobić coś nowego i dlatego zawsze odchodzą myślami od konkretnego bytu, takiego jakim on jest, stają się abstrakcyjni i rozkładają na części sytuację istniejącą, by ją następnie na nowo układać. W kategoriach kształtów, morfologicznie, widzi się tylko coś, co jest się gotowym zaakceptować, w czym się niczego nie chce zmienić; co więcej, pragnie się poprzez ujmowanie kształtu ustabilizować także to, co jest w nim w ruchu, pobłogosławić byt za to, że jest taki jaki jest ${ }^{12}$.
\end{abstract}

Rozróżnienie poczynione przez socjologa wiedzy wydaje się adekwatne także na obszarze socjologii nauki, zwłaszcza że znajduje dobre zastosowanie w odniesieniu do kwestii związanych z rzetelnością badawczą i etosem pracownika nauki, o którym pisała przed laty Stefania Skwarczyńska. Dla tego wybitnego teoretyka literatury nie ulegało wątpliwości, że działalność naukowa - poza kwalifikacjami ściśle profesjonalnymi - wymaga także odpowiedniego poziomu moralnego. Jej zdaniem, trzeba tu poddać się „swoistej ascezie, której wyznacznikiem jest wyrzeczenie i bezinteresowność", umiejętność przekroczenia swego „łatwego biologicznego 'ja”" i „odepchnięcia prostej witalności” po to, by poszukując prawdy nie mieszać porządków rzeczywistości „istniejącej”, „konstruowanej” i „nadprzyrodzonej” (dziś użylibyśmy raczej określenia - założonej bądź ideologicznie zadekretowanej). Im silniejsza w badaczu „prężność twórcza, im większa łatwość w rzutowaniu koncepcji, w konstruowaniu tez, powiązań, nici interpretacyjnych”, twierdziła Skwarczyńska, tym bardziej powinien on umieć „ograniczyć bujną ekspansywność własnego 'ja', wyrzec się najsłodszego z darów: nieskrępowanego tworzenia”. A powinien tak uczynić w imię szacunku dla poznawanej rzeczywistości, w imię „właściwego, uczciwego zachowania stosunku pomiędzy przedmiotem badania, owym światem rzeczywistości, bezbronnym wobec nas, biernym biernością przedmiotu, a zaborczą, prężną, dążącą do panowania nad przedmiotową rzeczywistością zdolnością twórczą naszego umysłu"13. Szkoda, że we współczesnej dyskusji nad zasadami uprawiania nauki, nie porusza się w Polsce tak fundamentalnych

${ }^{12}$ K. Mannheim, Ideologia i utopia, tłum. J. Miziński, Wydawnictwo Test, Lublin 1992, s. 224.

13 S. Skwarczyńska, Studia i szkice literackie, PAX, Warszawa 1953, s. 76. 
kwestii, jak te, na które zwracała uwagę Skwarczyńska, zawężając rozumienie etyki badacza do kwestii czysto warsztatowych oraz powinności wobec osób (respondentów i kolegów po fachu), ale już nie wobec rzeczywistości społecznej, którą - jak się to już utarło w praktyce z czasów PRL-u i z ostatnich dwudziestu lat - można bezkarnie krytykować, nawet szkalować i bezceremonialnie naginać do kolejnych wizji światopoglądowych. Tymczasem, jak pisała Skwarczyńska, ,jest dziwny prymitywizm w naszym odczuciu, że zło, krzywda istnieje tylko tam, gdzie kogoś niesprawiedliwość boli”, podczas gdy istota zła tkwi w samym „fakcie niesprawiedliwości” ${ }^{14}$. Zaniedbanie to tym bardziej niepokojące, że obecnie na zachodzie dokonuje się w humanistyce „zwrot etyczny”, rodzi się ruch „odrodzenia cnót” i formułowany jest program „epistemologii cnoty”, który nie odnosi się już tylko do zagadnień wąsko rozumianej metody, ale przenosi punkt ciężkości na zdolności poznawcze podmiotu, zgodnie z zasadą, iż „wiedza jest prawdziwym przekonaniem opartym na cnotach intelektualnych tego, kto wie"15.

Kolejną wartością bliską Profesor Wieruszewskiej jest sceptycyzm wobec uproszczonych schematów poznawczych, jakich nie brak nie tylko w myśleniu potocznym, ale również w nauce, zwłaszcza tej uprawianej zgodnie z aktualnym zapotrzebowaniem i administracyjnie egzekwowanymi dyrektywami. Tym właśnie należy tłumaczyć Jej skłonność do kontestowania uznanych twierdzeń i cierpliwego ich falsyfikowania przez stosowanie empirycznych sprawdzianów. Dzięki temu możliwe staje się zakwestionowanie wielu „oczywistych” prawd nauk społecznych, w rodzaju unifikującego wpływu industrializacji i urbanizacji w okresie PRL-u czy - aktualnie - modernizacji pod wpływem założeń Wspólnej Polityki Rolnej. Niezależnie od kształtu interwencji stosowanych wobec polskiej wsi

podstawowa struktura wsi w swych elementach konstytutywnych zachowuje trwałość i ciągłość - pisała w książce Wieś polska. Konteksty, kontrasty, strategie Rodzina, indywidualne gospodarstwo, krąg sąsiedzki, krewniaczy, grupy nieformalne i lokalne organizacje tworzą sieć stosunków i zależności, które utrzymują istotę społeczności do chwili obecnej, mimo destrukcyjnych nacisków makrostruktury państwa totalitarnego i wpływów kultury podporządkowującej ${ }^{16}$.

${ }^{14}$ Tamże, s. 83.

15 E. Domańska, dz. cyt., s. 182.

${ }^{16}$ M. Wieruszewska, Wieś polska. Konteksty, kontrasty, strategie, IRWiR PAN, Warszawa 1997, s. 25. 
„Na tym tle należałoby zweryfikować tezę o dezintegracji społeczności wiejskiej i szczątkowym charakterze powiązań nieformalnych, sąsiedzko-krewniaczych" - nie bez satysfakcji konstatowała Autorka kilka lat wcześniej ${ }^{17}$.

Można by to uznać za przejaw mityzacji, mitologizacji bądź ulegania agrarystycznym przesądom, gdyby wnioski nie były dobrze udokumentowane wynikami badań i gdyby do podobnych wniosków nie dochodzili także inni badacze, wywodzący się spoza uprzywilejowanego kręgu rodzimego main streamu. „Elementy tradycji, a zwłaszcza relacje rodzinne były w roku 1990 wciąż jeszcze najistotniejszymi czynnikami determinującymi funkcjonowanie polskiej wsi" - przyznaje badacz japoński, Etsuo Yoshino w książce Polscy chłopi $w X X$ wieku ${ }^{18}$. Przedkładając prawdę „rzeczywistości istniejącej” nad sugestywność „rzeczywistości konstruowanej” a zwłaszcza nad perswazyjną siłę „rzeczywistości zadekretowanej” Profesor Wieruszewska realizuje najważniejszą wartość wymienioną przez Skwarczyńską w katalogu etosu badacza, ale zarazem spełnia kryteria, jakie dla socjologa przewidywał Florian Znaniecki. Pisząc o nieuchronnej obecności schematów praktycznych i teoretycznych w funkcjonowaniu oraz poznawaniu życia społecznego Znaniecki przyznawał, że te schematy mogą być narzucane społeczeństwom, ale jednocześnie był świadom, iż rzeczywistość, z którą mamy wtedy do czynienia „nie jest już społeczna w sensie ścisłym”, a więc „naszym przedmiotem nie jest już grupa bądź osobowość jako typowa kombinacja różnorodnych schematów społecznych” zaś ludzie „są uważani wyłącznie za wsporniki danego systemu, za ukrytą podstawę, na której system zostaje urzeczywistniony"19. A skoro schematy wyparły konkretne elementy i zjawiska społeczne, tym samym trudno utrzymywać, iż badacz nadal zajmuje się socjologią, w związku z czym de facto sam przestaje być socjologiem. Przed takim właśnie ryzykiem skutecznie chroni postawa reprezentowana przez Jubilatkę, zwłaszcza stosowana przez Nią zasada „konkretu i kontekstu” oraz niechęć wobec postrzegania wsi w kategoriach abstrakcyjnych procesów rozwojowych czy też przez pryzmat kryteriów ekonomicznych i produkcyjnych.

\footnotetext{
17 Tejże, Odnowa wsi. Między mitem a nadzieją, IRWiR PAN, Warszawa 1992, s. 175.

${ }^{18}$ E. Yoshino, Polscy chłopi w XX wieku, Semper, Warszawa 1997, s. 24.

19 F. Znaniecki, Pisma filozoficzne, T. II, PWN, Warszawa 1991, s. 859.
} 
Wreszcie trzecia właściwość etosowego wymiaru perspektywy badawczej Profesor Wieruszewskiej, polegająca na śmiałym wykraczaniu poza istniejące paradygmaty i ukazywaniu nowych zastosowań refleksji nad rzeczywistością wiejską. W przekonaniu Jubilatki wieś nie jest reliktem ani zaściankiem współczesnego świata, nie jest także obszarem, na którym bezkarnie mogą prowadzić swe eksploracje specjaliści z innych dziedzin czy też eksperymentować decydenci różnych opcji politycznych, ale rodzajem wzorca i autorytetem dla kolejnych etapów cywilizacji, remedium na wiele kryzysów, jakie dotykają świat współczesny. Wskazując na absurdalność i krótkowzroczność istniejących tendencji rozwojowych, odnotowując z satysfakcją renesans wartości wspólnotowych, koncepcji lokalności czy idei neowiejskich Autorka formułuje tezę o potrzebie nawiązania do wartości chłopskich i wiejskich jako najbardziej adekwatnej odpowiedzi na dzisiejsze wyzwania.

Odrodzenie zainteresowań społecznością wiejską wiąże się przynajmniej z dwoma źródłami inspiracji - pisze w książce Wieś. W poszukiwaniu całości społeczno-kulturowej - Jednym jest rzeczywista tęsknota za wspólnotą, ładem, wartościami więzi prawdziwie silnej, bezpośredniej szczególnie widoczna w społeczeństwach Zachodu. Wartości te wypływają z potrzeby dialogu i tolerancji, coraz wyraźniej odczuwanej w świecie. Drugim źródłem inspiracji są wewnętrzne zmiany, jakie dokonują się w samej nauce, jej założeniach i metodach. Powrót do badań naturalnych społecznych całości, dążenie do interdyscyplinarnych podejść, jakby „w poprzek” dyscyplin, kieruje refleksję epistemologiczną w stronę społeczności, gdzie odnaleźć można podstawowe relacje w ramach wspólnoty, także bezpośrednie, autentyczne doświadczenia w relacji człowiek - środowisko, człowiek - człowiek ${ }^{20}$.

Ta deklaracja aksjologiczna jest zarazem (co należy wyraźnie zaznaczyć) postulatem radykalnego przeorientowania naukowych paradygmatów, a więc propozycją intensywnego, a nie jedynie ekstensywnego uprawiania nauki. Profesor Wieruszewska wskazuje te możliwości, ważne jednak, aby znaleźli się chętni do ich wykorzystania i do kontynuacji Jej dorobku.

${ }^{20}$ M. Wieruszewska, Wieś. W poszukiwaniu całości społeczno-kulturowej, IRWiR PAN, Warszawa 1991, s. 45. 


\section{BIBLIOGRAFIA}

- Bourdieu P., Zaproszenie do socjologii refleksyjnej, tłum. A. Sawisz, Oficyna Naukowa, Warszawa 2001.

- Bystroń J. St., Rozwój problemu socjologicznego w nauce polskiej, [w:] Sto lat socjologii polskiej, pod red. J. Szackiego, PWN, Warszawa 1995.

- Domańska E., Historia egzystencjalna, PWN, Warszawa 2012.

- Grabski W., System socjologii wsi, „Roczniki Socjologii Wsi” T. I, 1936.

- Mannheim K., Ideologia i utopia, tłum. J. Miziński, Wydawnictwo Test, Lublin 1992.

- Skwarczyńska S., Studia i szkice literackie, PAX, Warszawa 1953.

- Wieruszewska W., Dzieło „Chłop polski w Europie i Ameryce”, czyli o pożytkach z czytania klasyków, „Studia Migracyjne - Przegląd Polonijny” 2012, nr 2.

- Wieruszewska W., Odnowa wsi. Między mitem a nadzieją, IRWiR PAN, Warszawa 1992.

- Wieruszewska W., Samoorganizacja w społecznościach wiejskich, IRWiR PAN, Warszawa 2002.

- Wieruszewska W., Społeczność wiejska Zaborowa w procesie przemian, PWN, Warszawa 1980.

- Wieruszewska W., Tu i tam. Migracje z polskich wsi za granice, IRWiR PAN, Warszawa 2007.

- Wieruszewska W., Wieś polska. Konteksty, kontrasty, strategie, IRWiR PAN, Warszawa 1997.

- Wieruszewska W., Współczesne dyskursy na temat wsi i rolnictwa, [w:] Polacy o sobie, pod red. P. Kowalskiego, Oficyna Wydawnicza „Stopka”, Łomża 2005.

- Yoshino E., Polscy chłopi w XX wieku, Semper, Warszawa 1997.

- Znaniecki F., Pisma filozoficzne, T. II, PWN, Warszawa 1991.

\section{Professor Maria WieruSZeWSKa IN THE INSTITUTE of Rural and Agricultural Development (Polish Academy of Science)}

Professor Maria Wieruszewska has been working in Institute of Rural and Agricultural development form more than 40 years. She is interested in Polish country first of all. The main methodological instruction for her is principle "concrete and context" so the country is always showed in her books as open system which is a part of more general system. Professor Wieruszewska keeps her analysis very close to realities of local communities. She also calls in question popular opinions about country. Her explorations are connected with works and traditions of Polish ethnology and Polish rural sociology. It protects the identity of these domains and lets her to observe ethic principles of scientific research. 